\title{
Chinese Construction Enterprises in the Stream
}

\author{
Xin JIA \\ School of Water Conservancy and Environment \\ Zhengzhou University \\ Zhengzhou, China \\ e-mail: 420979646@qq.com
}

\author{
Jie LIAO \\ Zhengzhou engineering co., LTD \\ China railway seventh group co., LTD \\ Zhengzhou, China \\ e-mail: 75509501@qq.com
}

\author{
Liangming HU \\ School of Water Conservancy and Environment \\ Zhengzhou University \\ Zhengzhou, China \\ e-mail: liangmingh@zzu.edu.cn
}

\begin{abstract}
China's construction industry entered a new stage. For the construction enterprise that has been used for growing up in prosperity, there is undoubtedly full of challenges under the new normal. Construction industry profit has been low for a long time. Contract system prevailed. Competition among enterprises intensifies. How to improve enterprise competitiveness has already become the urgent matter. Deal frequent and informatization produced tremendous change to construction industry. Construction enterprises shall comply with the situation of economic policy; accelerate the deepening of the reform. Making enterprise strategy, improving the management level, breaking through the informatization and enhancing the core competitiveness, will become the path to the development of Chinese construction companies.
\end{abstract}

Keywords-construction enterprise; the construction industry; the new normal; competitiveness; opportunities and challenges

\section{INTRODUCTION}

With the rapid development of Chinese economy, the rapid growth of China construction industry remains $20 \%$ 30\%. And a large number of construction enterprises grow rapidly. The position of pillar industry in the national economy has been further consolidated and improved. However Chinese economic structure began to transition. Investment in fixed assets is beginning to slow. Labor, materials and energy era has passed and extensive management is being eliminated. With the progress of science and technology, there are many new concept such as BIM technology, Internet plus and Industrialization 4.0 are reshaping the traditional industries. China construction industry has begun to face a severe test. In the new normal, Chinese construction enterprises are sailing against the current and no progress means backwards. If you don't think of transformation, and absorb new nutrition, enterprises will face back even in rapids.

\section{EXISTING PROBLEMS OF CHINESE CONSTRUCTION ENTERPRISES}

\section{A. Low Profits of Construction Industry for a Long Time}

The construction industry is a high-risk (legal risk) and high risk (professional risk cost, quality and safety aspects) industry, but the acquisition profits and risks not become direct ratio. The so-called industry profit is low, reaction of corporate headquarters profit is low, and the project should not low profits. Due to the complexity of the industry and the backward management, lead to the low profits of enterprises headquarters. This seriously affects benign and sustainable development of the industry. Industry experts and entrepreneurs are generally believed that this is caused by two cases: one is excess capacity; the other is the backward mode of production. Excess capacity causes the owners to keep the prices down and vicious competition among enterprises. Production backward means the owners and design subcontractors division too much profit but leaving the construction unit is too little in the entire industry chain [1].

The number of general contracting enterprises is numerous. They fixate on competitiveness of relations and lack of unique core competitiveness. Consequently, low price competition becomes an inevitable means and low profit survival becomes the norm in the industry. At the same time, the backward management system and management ability of domestic construction enterprises, lead to enterprise be unable to carry out intensive management. Most private enterprise and more and more large state-owned enterprises take the project contract system as the main means of the number of projects and geographic expansion. Under the condition of headquarters control weakness, each link leak profit and cause losses to the project in the end. 


\section{B. The Headquarters of Construction Enterprise is Reduced to the Phenomenon of "Tax Bureau" and the Contract System Still Occupy the Mainstream}

The proportion of direct system projects has been reduced continuously in many domestic projects. Escrow contract system occupies the mainstream. Some enterprises even give priority to with the affiliated, collect management fees and make money from inside bank, just like a "tax bureau".

This phenomenon is mainly because when our country construction enterprise management scale expands rapidly, enterprise management capabilities have failed to simultaneously enhance and the project management mode is backward. Compared with other industries, there have more difficulties in the construction management. The complexity and difficulty of project management is mainly reflected in the non-standard products, production site mobility, teamwork instability, large amount of information and the most important point is that construction technology cannot be timely updating. The construction enterprise headquarters must pay attention to the improvement of the internal management level to make more profits from the project department to move upstream.

\section{Construction Enterprises Are Big but Not Strong. There Is No Benchmark and Lack of Corporate Strategy}

In 2016, the construction industry has a total of 21 enterprises shortlisted for the China Fortune 500. Dr. Yang Baoming said, Chinese construction enterprises depend on the high speed growth of China's construction industry and the huge scale. Enterprises are big but not strong. Big just represents a lot of subsidiary companies and project sampan splice. Strong enterprises should reflect on the key elements such as competition, profitability, market value and market share. Strong enterprises must have outstanding performance in customer value, employee value, shareholder value, social value. However, the domestic construction industry lack of such a large and strong industry benchmark.

Entrepreneurs have been busy with the relations with owners, the government and public. They are preoccupied with internal human relations settle, and fail to stop to study the purpose and reason of the enterprise. To make the enterprise bigger and stronger in the competition, entrepreneurs need to clear the enterprise strategy. The strategy of all firms in an industry are similar, it means that all enterprises in this industry are not what strategy. At present Chinese large-scale construction enterprise strategic convergence, leading to the market can not to choose. It becomes more urgent and important to produce model enterprises.

\section{The Construction Industry Threshold Is Low. The Competition between Enterprises Is Increasing}

General contracting enterprises neglect the enterprise internal strength increase and lack of real core competitiveness. There is no competition threshold for new entrants in the brand, technology, capital operation, purchasing and cost control. Construction enterprise access threshold is low and the industry order is relatively confused.
Especially, the present situation of the construction industry in our country is not in the scale of economy for a long time. The cost of large enterprises is higher than that of small enterprises. Small business costs higher than individual contractors. This China construction industry present situation of diseconomies of scale lead to vicious price competition cannot be avoided. Most of the domestic construction enterprises believe in the concept of relationship competitiveness and money making idea. There has no breakthrough in management due to the limitations of management, technical means, and methodology. The gap between the levels of enterprise management is not open and it is difficult to establish competitive advantage. So the industry has been in a melee.

\section{NEW NORMAL CONSTRUCTION}

In recent years, China has gradually entered a new normal. Economic growth, economic structure and development patterns are changing. In May 2014, the CPC Central Committee General Secretary Xi Jinping said in Henan. Chinese development is still in an important period of strategic opportunities. We need to enhance confidence, start from the current stage of China's economic development, adapt to the new normal and maintain a normal state of mind strategy. This is the first time the central leaders to describe the new period of China's economy in the "new normal". With the national economy into the new normal, the construction industry has also entered the new normal era. Under the new normal, construction industry growth slows sharply and investment continues to decline. Real estate collapses. Labor costs rises rapidly. The project payment becomes difficult. Competition increases. PPP model with a high risk begins to prevail.

\section{A. The New Policy Impact on Construction Industry}

In the third Plenary Session of the 18th CPC Central Committee November 2013 released "decision of the CPC Central Committee on deepening reform of several major issues", this means a comprehensive deepening of reform. This will affect the entire construction industry to accelerate the transition from the relationship to competitiveness. Opportunities will be increased for those who have the ability. The degree of marketization is improving. Anti-corruption efforts are increasing. Political and legal risks are also increasing. To grasp the future, construction enterprise competition strategy need to be thoroughly changed. Strategic competitiveness, brand competitiveness, project management capabilities will increasingly become the core competitiveness of the most important.

In July 2014, in response to the comprehensive deepening of reform, the Ministry of Housing and Urban Development released "several opinions about promote the development and reform of the construction industry", The document stresses the core idea of the third Plenary Session of the 18th CPC Central Committee -give full play to the decisive role of the market in the allocation of resources and design system and allocation of market resources. The goal of reform is to open up a fair national construction market system, innovative market quality and safety supervision and 
management mechanism, and promote the modernization of the construction industry. The construction industry is deeply affected by the planned economic system. Until now the regulation model is still the main government management, supplemented by market. It will be a long way to go to the de-administration and be market-oriented.

In February 2016, the State Council issued the "Opinions of the State Council on promoting the construction of new urbanization". The new urbanization of the "new" is change from the past one-sided emphasis on the pursuit of the expansion of the city and spatial expansion, to enhance the city's cultural and public services as the center. The development of urbanization cannot be separated from the support of the construction industry. Chinese construction enterprises are undoubtedly the beneficiaries. But this and the previous round of construction will have a big different. The project features will not be big difficult but for low carbon, higher green construction requirements and more demand on ability to project judgment. Therefore, new urbanization funding problems will be more serious. Government financing capacity and developer financing capacity are greatly restricted. Under the circumstances, PPP project will be popular.

In March 2016, Financial Department, the State Administration of Taxation jointly issued "notice of a fully open business tax VAT pilot's". The construction industry has always been an important part of our national economy. Its annual tax revenue accounts for a large part of the country's total fiscal revenue. All along, the state for the construction industry's tax policies is subject to pay sales tax. This kind of tax policy increases the chance of repeating tax, affecting the company's operating income. Value added tax reduces the probability of repeated enterprise tax so that the construction enterprises have the opportunity to adjust the pattern. On the one hand, VAT can reduce the corporate tax pressure, promote the overall innovation of enterprises, and promote enterprise internal coordination and stability. But on the other hand, VAT also has many difficulties. Such as construction workers payrolls are difficult. Corporate finance related system is obsolete. The accounting department and related personnel lack of professional skills. Enterprise assets accounting processes is difficult [2]. Promote VAT, suggests that reform is complicated and arduous progress. Construction enterprises should seize the opportunity and implement various reform programs and measures to be more perfect integration into the new era.

\section{B. PPP Model, the Internet +BIM and Other New Concepts Triggered by the Industry Change}

PPP means the government and social capital cooperation to provide infrastructure and public services. Cooperation with social capital (PPP) has become the main mode of local government to provide public goods and services from October 2014 the State Council issued 43 text which means the end of the local government financing platform and the traditional financing mode. The benefits of PPP mode is mainly manifested in four aspects: first, under the big situation that the traditional main business competition is fierce and profit margins fall sharply, construction enterprises participate in government programs with the help of PPP model and form a long-term cooperative relationship with the government. It will change the main body of the building or the identity of the main body of debt in the past into a holder of the relevant rights and interests of the project. And it promote the transformation and upgrading of construction enterprises; The second is that construction enterprise as a social investor PPP project side, is no longer a simple construction unit. Construction enterprises contract more initiative in specific project even lead the project operation; the third is construction enterprises can extend investment channels in the main business of traditional chain. Large state-owned construction enterprises develop the specialized investment system to realize the integration of investment and the balanced development. It brings investment income to enhance the enterprise, reduces financial costs and achieves the daily stable cash flow; the fourth is construction enterprises can participate in the field of business focus or familiar with the field of late project operations through the PPP model. It makes the enterprise to extend the main business chain (such as medical, education, energy conservation and environmental protection, rail transportation). But the profit and risk is a pair of non separable economic factors. High returns are often accompanied by high risk. The risk of PPP model is mainly reflected in the government's legal system, the incomplete management mechanism, the government and enterprise management and management philosophy differences, decision-making errors. How to scientifically deal with the risk has become the most important issue for the construction enterprises to use the PPP model [3].

At present, BIM Technology (Information Modeling Building) is no longer the industry's cutting-edge technology, but the industry's obvious trend and the construction enterprise strategy. BIM can achieve the transparency of engineering quantity and auxiliary transparent to other information; The Internet, on the one hand, Help BIM technology to realize the collaboration and sharing of wide area network. On the other is to make the product price, consumption index and cost data information to be transparent. Dr. Yang Baoming said that the construction industry is by far the most opaque industry and has many industry problems, social problems; the construction industry is most in need of the Internet, revolution of BIM technology; It can liberate productivity, reduce the consumption of resources staggering and the resulting social benefits will be very considerable.

"Internet + BIM" is a technical revolution in the construction industry. It improves the production efficiency, enhances the quality of building products, promotes industry transparency, promotes the transition from the relationship between competitive ability to the competitiveness of the industry, forms the advantage of scale economy of the construction industry and accelerates industrial integration. More and more owners, as the biggest beneficiary of BIM technology, are paying attention to the BIM technology to enhance the level of project operation across the country. More and more large and complex projects across the 
country will be listed as the BIM technology tender terms, which mean that companies that do not apply BIM technology are not eligible to participate in the bidding of the project directly. "Internet + BIM" is a new opportunity for reformers while it is a disaster for old fogies. The enterprise should make good use of this tool, in order to greatly enhance the project implementation capacity and reduce the cost.

\section{SEIZE THE OPPORTUNITY AND FACE THE CHALLENGE}

Management Master Peter Drucker said, environmental change is not terrible, terrible is the use of this last is not logic. New urban market development under the new normal, the opportunity brought by new urbanization and information technology industry are gradually emerged. Opportunities and challenges will be greater than ever. If enterprises continue to drift that will lose the best period of adjustment, and gradually lose their ability to survive.

\section{A. Strategic Winning; Improve Own Competitiveness}

With the end of the era of the rapid growth of the industry, the whole industry will be in the public relations war, price war, and vicious competition in the industry. The real strategy should be positioned by the difference, clearly establish the brand in the minds of customers, focus on brand positioning for the allocation of resources, build more and more barriers to competition in multiple the related value chain, greatly enhance the competitiveness, strengthen their own advantages, in order to get rid of vicious competition. A long-term focus, you can quickly progress. Full attack, it is difficult to highlight and succeed in the homogenization of competition.

\section{B. Pay Attention to the Internal Management and Transformation to the Retail System}

In the face of the extensive management of the construction enterprise, the construction enterprise must pay attention to the improvement of the internal management level. Firstly, it is very necessary to introduce the modern enterprise management theory in construction enterprise and build efficient management organization structure. Improve the internal management level of construction enterprise is the key to realize the successful transformation of the construction enterprise. The internal management level of construction enterprise promotion should first enhance the management ability of the management level and the cognition of the modern architecture enterprise management theory, unify management layer on the current status of the development of construction enterprises and the correct understanding of the problem. Secondly, the construction of scientific management is reflected in the introduction of a comprehensive budget management system in the enterprise and improving enterprise management efficiency. Finally, the enterprise should attach importance to the introduction of the concept of modern human resources management, pay attention to the construction of talents training and team building. In short, through the continuous improvement of the management level, it can effectively improve the competitiveness of enterprises; reduce the operating costs of enterprises, so as to gain more market opportunities for enterprises [4].

\section{Breakthrough in Information Technology and Accelerate the Implementation of Intensive Management}

With the development of science and technology, advanced technology has a significant role in promoting the development of the industry. The advantage of scale economy of construction industry can be achieved, and can continue to enlarge because of the big data era. If enterprises want to break through the project fine management and implementation of enterprise intensive management, data capacity is the first point and cannot be avoided. The core business of construction, transformation and upgrading of enterprises also must possess the basic ability of data. Therefore, we must try our best to break through the information. In recent years, BIM technology, the Internet BSNS and Wiki technology have development and matured, so that the construction of the development of the information industry has taken a big step forward. As soon as possible to enhance the capacity of enterprise and project data, the enterprise has no time to delay.

\section{REFERENCES}

[1] Yang Baoming. "Break Out - New thinking on the transformation and upgrading of Chinese construction enterprises". Beijing: Construction Industry Press, 2015, pp.3-26.

[2] Liang Xiujuan. "Opportunities and challenges for construction enterprises under value added tax". Accounting Learning, vol.2, Jan.2016, pp.109, 118, ISSN: 1673-4734.

[3] Dai Yonghua. "Discussion on the opportunity and risk of PPP model for construction enterprise". Money China, vol.24, Sep.2015, pp.114-115, ISSN: 1009-2781.

[4] Qian Suyun, "Construction enterprise market competitiveness improvement under the new normal”. Marketing Research.vol.022, Apr.2016, pp.50-52, DOI: 10.13999. 